\title{
Analysis of Mangrove Species Distribution Mapping and the Environmental Problem in Mangkang Kulon, Semarang City
}

\author{
Tjaturahono Budi Sanjoto ${ }^{*}$, Vina Nurul Husna ${ }^{2}$, Wahid Akhsin Budi Nur Sidiq ${ }^{3}$ \\ 1,2,3 Geography Department, Universitas Negeri Semarang, Indonesia \\ *Corresponding author.Email: tjatur@mail.unnes.ac.id
}

\begin{abstract}
The pressure on mangrove forest have been increasing due to abrasion and industrial development. Mangkang Kulon Sub-district as one coastal area in Semarang City experience loss of mangrove and coast itself due to abrasion from pond activities. We use Spectral Angle Mapper to classify species of mangrove in Mangkang Kulon. Spectral library was obtained from fieldwork using USB 4000. As the result, Spectral Angle Mapper successfully mapping distribution of species of mangrove in Mangkang Kulon. The area of mangrove in Mangkang Kulon is about 8.6 hectares or only $2 \%$ of Mangkang Kulon. Most of the mangrove in Mangkang Kulon is Bruguiera gymnorrhiza, followed by Rhizophora mucronata and Xylocarpus granatum. For future existence of mangrove ecosystem in Mangkang Kulon, several methods have been utilizing to improve extend and quality of mangrove.
\end{abstract}

Keywords: mangrove, mapping, spectral angle mapper, Mangkang Kulon.

\section{INTRODUCTION}

Indonesia is an archipelago country with the longest coastline after Canada [1]. The total area of mangrove forest in Indonesia is estimated to be around \pm 3 million hectares and declining [2]. Mangrove is one of the most productive ecosystems on the earth. Mangroves are forests with halophytic vegetation that can be found in coastal areas, especially in estuaries and lagoons in tropical and subtropical areas which have important ecological and socio-economic functions [3]. Mangrove ecosystems have a very important role in terms of the dynamics of the coastal and oceanic environment itself, including sources of organic matter and nutrients [4] as a habitat for various types of fish and shrimp to find food, spawn, shelter and lay eggs [5], habitats of various types of fauna [6], [7], can be used as a medium of learning and recreation [8], [9], sequestering carbon in global climate change [10][11][12], protecting the coast from erosion, wind, and waves [13] and producing timber and other resources [14].

However, Indonesia's mangrove ecosystem faced consequential loss due to aquaculture development, urbanization, and agriculture [15]. Nearly one million hectares of mangrove forests in Indonesia have been deforested since 1800 , of which $80 \%$ is used for aquaculture development. Indonesia's annual mangrove loss is only six percent of total forest loss, but the impact is up to $31 \%$ of carbon emission in the land-use sector [16]. Mangroves will become extinct and soon become a part of history [17]. The conservation of the mangrove ecosystem's high carbon stock is vital to tackle climate change in the land-use sector [18]. Supporting conservation needs more reliable mangrove condition data, including its species and distribution. The main problem is the data that had been provided by the government is not up to date and hard to identify the mangrove change. Rahadian et al. [2] stated that mangrove biodiversity data is a national problem given the importance of historical mangrove data on accurate and consistent. This data is very useful for developing policies in mangrove management. In recent years, to fill that gap, remote sensing data has successfully provided mangrove ecosystem information [19]. The mangrove data usually describe the only information mangrove and not mangrove, without information of species. Indeed, the mangrove species information is important in mangrove management [20] [21]. Landuse change that is not in accordance with their designation has made the mangrove area degraded increasingly. The reduced area of mangrove land has certainly led to the loss of mangrove species in the area.

The dynamic of mangrove extend also in Mangkang Kulon, Semarang [22]. Mangrove area has decreased periodically but in the last decade has increased in the area. The increase in mangrove area is due to the Semarang City Spatial Plan (RTRW) for 2011-2031 which states that Mangkang Kulon is one of the areas included in the mangrove forested coastal area. From this regulation, the mangrove area in Mangkang Kulon can be maintained and even 
expanded. However, the next problem arises, namely the development of a very massive industrial area around the mangrove area. This certainly threatens the existence of mangroves. Mangroves can be damaged due to industrial pollution and also the mangrove area can be reduced due to land conversion.

This research aims to monitor the distribution of mangrove species. Mapping of mangrove species is used to improve the quality of mangrove distribution data which can then be used as a guide to continue the mangrove rehabilitation process in Mangkang Kulon. This research involves remote sensing technology to facilitate the identification of species using the Spectral Angle Mapper (SAM) algorithm. Remote sensing has been widely used for mangrove mapping with different degrees of success [23][24]. In addition, this study aims to determine the condition of the mangroves of Mangkang Kulon and the role of the community in the conservation of mangrove areas.

\section{METHOD}

\subsection{Study Area}

This research was conducted in the coastal area of Mangkang Kulon Sub-district, Tugu District, Semarang City, Indonesia (Figure 1). We choose this area because it has degraded mangrove ecosystem due to excessive and unsustainable pond development. As a result, this Sub-district has experienced abrasion and pollution from industrial waste. However, the restoration initiative has taken action to restore mangrove condition. Because main livelihood of Mangkang Kulon Sub-district is fish farmer (aquaculture) and fishermen, that relying their sustainable income on environment condition of coastal area [25].
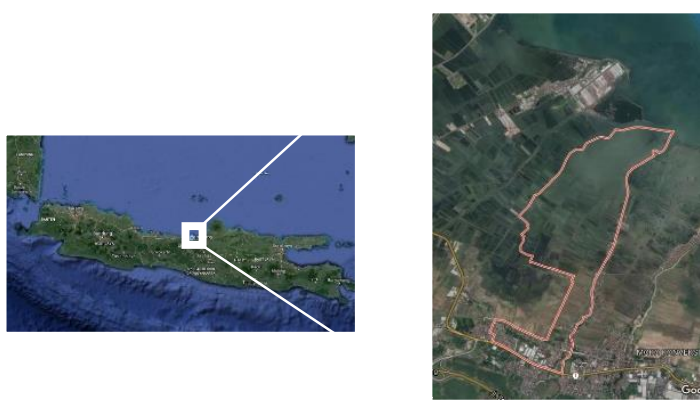

Figure 1. Map of study area in Mangkang Kulon Sub-district, Semarang City.

\subsection{Data and Analysis}

Mangrove species distribution obtained with remote sensing method. We used the SPOT 7 image that was acquired on 24 December 2019. SPOT 7 image has 4 multispectral bands with 6-meter spatial resolution and one panchromatic band with $1.5-\mathrm{m}$ spatial resolution. The image was corrected on radiometric and atmospheric using Fast Line-of- sight Atmospheric Analysis of Hypercubes (FLAASH) method.

Field work was done on 14 - 15 August 2020. We used spectrometer USB 4000 (sensitivity 380 $1100 \mathrm{~nm}$ ) to measure spectral response of eight mangrove species: Avicennia marina, Bruguiera gymnorrhiza, Ceriops tagal, Rhizophora apiculata, Rhizophora mucronata, Rhizophora stylosa, Sonneratia, and Xylocarpus granatum. Mangrove species reflectance was measured by directing the sensor from the spectrometer to the mangrove leaf at an angle of $45^{\circ}$ with a distance of approximately $5 \mathrm{~cm}$ from the leaf surface. Spectral measurement is carried out on clear weather from 9:00 to 11:00 AM. To calculate the reflectance of the in-situ measurement results can use the following equation:

$$
R \lambda=\frac{S \lambda-D \lambda}{R e f \lambda-D \lambda} \times 100 \%
$$

Where:

$R \lambda$ : Reflectance (\%)

$S \lambda$ : Sample intensity (counts)

$D \lambda$ : dark reference intensity (counts)

$\operatorname{Ref} \lambda$ : white reference intensity (counts)

After collecting spectral library from field measurement, the mangrove species classification using SPOT 7 image were carried out using Spectral Angle Mapper (SAM) as following equation:

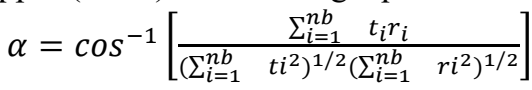

Where:

$\alpha$ : spectral angle

$\mathrm{nb}:$ number of band $(\mathrm{N}=4)$

$\mathrm{t}$ : pixel value

$\mathrm{r}$ : spectral library

In the field work we also collected secondary data about general condition of mangrove in Mangkang Kulon Sub-district.

\section{RESULT}

\subsection{Mangrove in Mangkang Kulon}

Table 1 shows the area of mangrove is about 8.6 hectares or only $2 \%$ of Mangkang Kulon. This result lower compare [22] because of different spatial resolution, which in this research was lower resolution. Hence our classification didn't detect small existence of mangrove tree such as from restoration project and based only from spectral library. There is a possibility an mixture mangrove spectral and other vegetation due to scattered distribution. 
Table 1. Mangrove extend according SAM's classification

\begin{tabular}{|c|l|c|}
\hline No & Mangrove Species & Area (Ha) \\
\hline 1 & Avicennia marina & 0.4 \\
\hline 2 & Bruguiera gymnorhiza & 3.8 \\
\hline 3 & Ceriops tagal & 0.9 \\
\hline 4 & Rhizophora apiculata & 0.4 \\
\hline 5 & Rhizophora mucronata & 0.5 \\
\hline 6 & Rhizophora stylosa & 1.6 \\
\hline 7 & Sonneratia & 0.0 \\
\hline 8 & Xylocarpus granatum & 1.0 \\
\hline Total & & 8.6 \\
\hline
\end{tabular}

Most of the mangrove in Mangkang Kulon is Bruguiera gymnorrhiza, followed by Rhizophora mucronata and Xylocarpus granatum. The distribution of mangrove species as explained in Figure 2, shows Avicennia marina dominates the sea-facing area because of its high adaptation with salinity. While other species scattered without

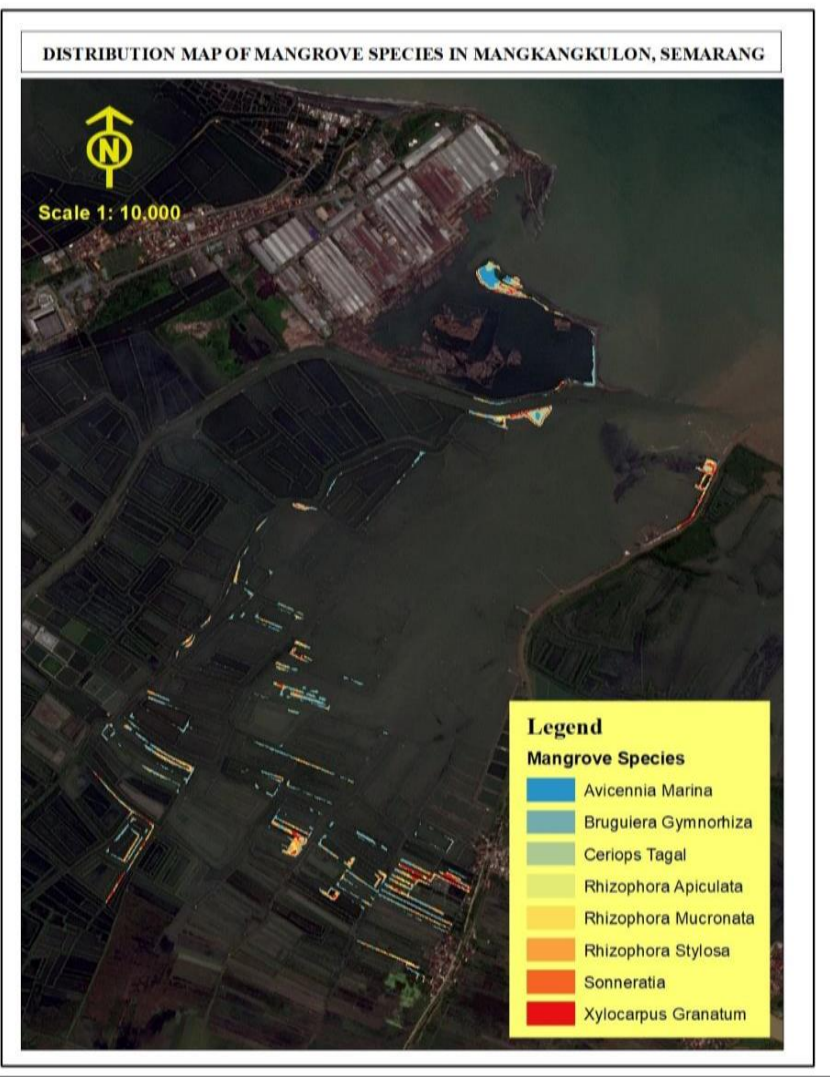

pattern or mangrove zonation.

Figure 2. Map of mangrove distribution from SAM Classification in Mangkang Kulon.

The result of identification of the mangrove species using SAM algorithm performed accuracy assessment using 'Error Matrix'. The error matrix method to assess accuracy found overall accuracy is only $52 \%$. This means that only half of the classified mangrove area has the correct species or according to the conditions in the field. The reason for lower accuracy is from the sparse of Bruguiera and Sonneratia distribution. Sparse distribution lead to increased background noise from land-use around Bruguiera and Sonneratia such as ponds and road. The condition in the field, there are only a few trees of Bruguiera and Sonneratia so the reflectance recorded by the sensor is disturbed by the reflectance from fish pond.

From our observation, there is a lack of mangrove zonation in Mangkang Kulon because of two things. First, the mangrove ecosystem is not in a natural condition which was initially deforested for aquaculture development. Unsustainable practice made the ponds degenerated due to sea abrasion. Hence the shoreline moves into inland that makes mangrove regrowth in different initial zonation. Also, mangrove never regrows in the pond area where it is always inundated because it has no surface soil even in low tide.

Second, with degraded ecosystems, local communities started restoration programs to prevent further abrasion. The restoration program did not incorporate zonation as the main factor, but only depended on seedling availability. The result is that several species grow not in their initial habitat. For example, planting activities makes the existence of Xylocarpus granatum increase in Mangkang Kulon. But this species does not-optimally grow because of unsuitable salinity. However, community participation in planting and conserving mangrove ecosystems is a good starting point in preventing further loss.

\subsection{Environmental Factor Affecting Mangrove Distribution}

Mangrove area in Mangkang Kulon always fluctuates year to year, both in area and quality. Tugu District, which oversees Mangkang Kulon, has special attention on mangrove ecosystem preservation and conservation. According Semarang City Spatial Planning (RTRW) 2011-2031, Tugu District becomes one of area for coastal conservation especially mangrove ecosystem. Restoration program is inevitable as part of program to accelerate mangrove extend area. Despite the extend of mangrove increase, it not accompanied with the improvement of quality itself.

[26] reported heavy metal pollution ( $\mathrm{Fe}$ and $\mathrm{Pb}$ ) was identified in coastal Tugu District as long in Mangkang Kulon. These heavy metals come from industrial activities which are growing rapidly around the mangrove area. Even these heavy metals have accumulated in the sediments and bodies of mangrove plants [27]. Mangroves are vegetation that has biofilter capabilities, namely the ability to absorb, bind and trap pollution in order to produce water that will flow into the sea cleaner or free from 
polluting substances. From the ability of the biofilter, it can be concluded that mangroves can be one of the bioindicators for an environment. If the mangrove contains heavy metals, the waters around the mangrove are also contaminated with these heavy metals.

\section{DISCUSSION}

Spectral Angle Mapper successfully mapping distribution of species of mangrove in Mangkang Kulon. This research mirrored research from [28] and [29] that SAM has potential for extracted mangrove species distribution using remote sensing. This application supports an effort for mangrove conservation in long-term monitoring. In the case of Mangkang Kulon mapping, the limitation of this method is only relying on spectral libraries. Health conditions of mangrove influence the leaf spectral, hence affect classification class. But the result showed promise because it could detect smaller patches on scattered mangrove distribution on Mangkang Kulon.

For the future existence of the mangrove ecosystem in Mangkang Kulon, several methods have been utilized to improve extent and quality of mangrove. Main approach alongside the restoration program is initiated mangrove for tourist destinations. Restoration itself successfully increased mangrove distribution which was conducted by government agencies, private companies, and empowered local coastal communities [22]. The derivative product is EduEco Mangrove Tourism which supports restoration both in community and financial [30]. In Mangkang Kulon, the process of mangrove rehabilitation and re-utilization of mangroves is still ongoing. It is important to gain support from the government both from policy and finance to improve the quality of mangrove.

\section{CONCLUSION}

Spectral Angle Mapper successfully mapping distribution of species of mangrove in Mangkang Kulon. The area of mangrove in Mangkang Kulon is about 8.6 hectares or only $2 \%$ of Mangkang Kulon. Most of the mangrove in Mangkang Kulon is Bruguiera gymnorrhiza, followed by Rhizophora mucronata and Xylocarpus granatum. For future existence of mangrove ecosystem in Mangkang Kulon, several methods have been utilizing to improve extend and quality of mangrove. Main approach alongside with restoration program is initiated mangrove for tourist destination

\section{ACKNOWLEDGMENTS}

The author would like to thank Dr. Suwito Eko Pramono, M.Pd as the Head of the Se-marang State
University of Research and Community Service Institute, who has provided funds to achieve this research. We would like to thank Mr. Sururi for giving permission and providing instructions during field measurements. Also, for National Aeronautics and Space Agency for give opportunity and provide SPOT 7 data for this research.

\section{REFERENCES}

[1] R. Dahuri, "Pre- and Post-tsunami Coastal Planning and Land-use Policies and Issues in In-donesia.," Proceeding Work. Coast. Area Plan. Manag. Asian Tsunami-affected Country. Food Agric. Organ. United Nation, 2007.

[2] A. Rahadian, L. B. Prasetyo, Y. Setiawan, and K. Wikantika, "Tinjauan historis data dan informasi luas mangrove Indonesia ( A Historical Review of Data and Information of Indonesian Mangroves Area )," Media Konserv., vol. 24, no. 2, pp. 163-178, 2019, doi: 10.29243/medkon.24.2.163-178.

[3] FAO, “The world's mangroves 1980-2005. A thematic study prepared in the framework of the global forest resources assessment 2005," FAO For. Pap., 2007.

[4] J. Haryadi and Hadiyanto, "KORELASI NUTRIEN TERLARUT DENGAN STRUKTUR KOMUNITAS PLANKTON DI TAMBAK MANGROVE BLANAKAN, KAB . SUBANG Correlation of Dissolve Nutrient to Plankton Community Structure in Mangrove Pond," J. Pengelolaan Sumberd. Alam dan Lingkung., vol. 2, no. 2, pp. 73-84, 2012.

[5] M. Zagars, K. Ikejima, A. Kasai, N. Arai, and P. Tongnunui, "Trophic characteristics of a mangrove fish community in Southwest Thailand: Important mangrove contribution and intraspecies feeding variability," Estuar. Coast. Shelf Sci., vol. 119, no. March, pp. 145-152, 2013, doi: 10.1016/j.ecss.2013.01.005.

[6] D. Saudamini, "Ecological Restoration and Livelihood: Contribution of Planted Mangroves as Nursery and Habitat for Artisanal and Commercial Fishery," World Dev, vol. 94, pp. 492-502, 2017.

[7] J. Y. S. Leung, "Habitat heterogeneity affects ecological functions of macrobenthic communities in a mangrove: Implication for the impact of restoration and afforestation," Glob. Ecol. Conserv., vol. 4, no. July 2015, pp. 423-433, 2015, doi: 10.1016/j.gecco.2015.08.005.

[8] D. Wijayanto, D. M. Nuriasih, and M. N. Huda, "STRATEGI PENGEMBANGAN PARIWISATA MANGROVE DI KAWASAN KONSERVASI PERAIRAN NUSA PENIDA 
(Strategies of Mangrove Tourism Development in Nusa Penida Marine Protected Area)," $J$. Saintek Perikan., vol. 8, no. 2, pp. 25-32, 2013, doi: 10.14710/ijfst.8.2.25-32.

[9] M. A. Salam, G. R. Lindsay, and M. C. M. Beveridge, "Eco-tourism to protect the reserve mangrove forest the Sundarbans and its flora and fauna," Anatolia, vol. 11, no. 1, pp. 56-66, 2000, doi: 10.1080/13032917.2000.9686983.

[10] E. Hilmi et al., "The carbon conservation of mangrove ecosystem applied REDD program," Reg. Stud. Mar. Sci., vol. 16, no. August, pp. 152-161, 2017, doi:

10.1016/j.rsma.2017.08.005.

[11] N. Ahmed and M. Glaser, "Coastal aquaculture, mangrove deforestation and blue carbon emissions: Is REDD+ a solution?," Mar. Policy, vol. 66, pp. 58-66, 2016.

[12] D. M. Alongi, "Carbon sequestration in mangrove forests," Carbon Manag., vol. 3, no. 3, pp. 313-322, 2012, doi: 10.4155/cmt.12.20.

[13] D. M. Alongi, "Mangrove forests: Resilience, protection from tsunamis, and responses to global climate change," Estuar. Coast. Shelf Sci., vol. 76, no. 1, pp. 1-13, 2008, doi: 10.1016/j.ecss.2007.08.024.

[14] A. A. Azis, P. Dargusch, S. Phinn, and A. Ward, "Using REDD+ to balance timber production with conservation objectives in a mangrove forest in Malaysia," Ecol. Econ., 2015.

[15] M. Ilman, P. Dargusch, P. Dart, and Onrizal, "A historical analysis of the drivers of loss and degradation of Indonesia's mangroves," Land use policy, vol. 54, pp. 448-459, 2016, doi: 10.1016/j.landusepol.2016.03.010.

[16] D. Murdiyarso et al., "The potential of Indonesian mangrove forests for global climate change mitigation," Nat. Clim. Chang., vol. 5, pp. 1089-1092, 2015.

[17] Julkipli, R. R. Batubara, G. E. Jogia, I. Batubara, K. A. Audah, and K. N. Nunuk, "Introduction of bioprospecting opportunities for Indonesian mangrove species," IOP Conf. Ser. Earth Environ. Sci., vol. 183, no. 1, pp. 813, 2018, doi: 10.1088/1755$1315 / 183 / 1 / 012013$.

[18] D. M. Alongi, "Global Significance of Mangrove Blue Carbon in Climate Change Mitigation," Sci, vol. 2, no. 3, p. 67, 2020, doi: 10.3390/sci2030067.

[19] T. D. Pham, N. Yokoya, D. T. Bui, K. Yoshino, and D. A. Friess, "Remote sensing approaches for monitoring mangrove species, structure, and biomass: Opportunities and challenges," Remote Sens., vol. 11, no. 3, pp. 1-24, 2019, doi: $10.3390 /$ rs11030230.

[20] S. C. Atkinson et al., "Prioritising mangrove ecosystem services results in spatially variable management priorities," PLoS One, vol. 11, no. 3, pp. 1-21, 2016, doi: 10.1371/journal.pone.0151992.

[21] J. Chow, "Mangrove management for climate change adaptation and sustainable development in coastal zones," J. Sustain. For., vol. 37, no. 2, pp. 139-156, 2018, doi: 10.1080/10549811.2017.1339615.

[22] N. K. T. Martuti, R. Pribadi, N. K. Dewi, W. A. B. N. Sidiq, and S. B. Nugraha, "The Dynamics of Coastline and Mangrove Ecosystems in Coastal Area of Mangkang Kulon Subdistrict, Semarang," IOP Conf. Ser. Earth Environ. Sci., vol. 550, no. 1, 2020, doi: $10.1088 / 1755-1315 / 550 / 1 / 012011$.

[23] C. Kuenzer, A. Bluemel, S. Gebhardt, T. V. Quoc, and S. Dech, Remote sensing of mangrove ecosystems: A review, vol. 3, no. 5 . 2011.

[24] N. N. Salghuna and R. C. P. Pillutla, "Mapping Mangrove Species Using Hyperspectral Data: A Case Study of Pichavaram Mangrove Ecosystem, Tamil Nadu," Earth Syst. Environ., vol. 1, pp. 1-12, 2017.

[25] K. Dewi, "Pelapisan Sosial-Budaya Pesisir Kelurahan mangkang Kulon, Semarang," Sabda J. Kaji. Kebud., vol. 13, no. 1, 2018, [Online]. Available: http://dx.doi.org/10.1016/j.cirp.2016.06.001\%0 Ahttp://dx.doi.org/10.1016/j.powtec.2016.12.0 55\%0Ahttps://doi.org/10.1016/j.ijfatigue.2019. 02.006\%0Ahttps://doi.org/10.1016/j.matlet.201 9.04.024\%0Ahttps://doi.org/10.1016/j.matlet.2 019.127252\%0Ahttp://dx.doi.o.

[26] M. Yusuf, "Dampak Pencemaran Terhadap Kualitas Perairan dan Strategi Adaptasi Organisme Makrobenthos di Perairan Pulau Tirangcawang Semarang," ILMU Kelaut. Indones. J. Mar. Sci., vol. 9, no. 1, pp. 41-49, 2004, doi: 10.14710/ik.ijms.9.1.41-49.

[27] A. Kariada, Nana., Irsadi, "PERANAN MANGROVE SEBAGAI BIOFILTER PENCEMARAN AIR WILAYAH TAMBAK BANDENG TAPAK, SEMARANG ( Role of Mangrove as Water Pollution Biofilter in Milkfish Pond, Tapak, Semarang ) Nana Kariada T . M . * dan Andin Irsadi Jurusan Biologi, Fakultas MIPA, Unive," J. Mns. Dan Lingkung. Mns. Dan Lingkung., vol. 21, no. 2, pp. 188-194, 2014. 
[28] X. Su, X. Wang, J. Zhao, K. Cao, J. Fan, and Z. Yang, "Improved Spectral Angle Mapper applications for mangrove classification using SPOT5 imagery," Open Sci. Discuss., pp. 125, 2019.

[29] M. Kamal, M. U. L. Ningam, F. Alqorina, P. Wicaksono, and S. H. Murti, "Combining field and image spectral reflectance for mangrove species identification and mapping using WorldView-2 image," no. October, p. 60, 2018, doi: 10.1117/12.2325629.

[30] W. A. B. N. Sidiq, N. K. T. Martuti, A. Irsadi, and D. P. Mutiatari, "Development of Maroon Mangrove Education Park (MMEP) in Supporting Mangrove Conservation in Coastal of Semarang City," IOP Conf. Ser. Earth Environ. Sci., vol. 747, no. 1, 2021, doi: 10.1088/1755-1315/747/1/012067. 